\title{
A Serratia marcesens Strains Involved in Cotton (Gossypium hirsutum) Boll Infection by a Prokaryote
}

\author{
Enrique G. Medrano $^{1 *}$ (), James P. Glover ${ }^{2,3}$, Alois A. Bell'1, Michael J. Brewer ${ }^{2}$ \\ ${ }^{1}$ Insect Control \& Cotton Disease Research Unit, United States Department of Agriculture-Agricultural Research Service \\ (USDA-ARS), College Station, TX, USA \\ ${ }^{2}$ Texas AgriLife Research and Extension Center, Department of Entomology, Texas A\&M University, Corpus Christi, TX, USA \\ ${ }^{3}$ USDA-ARS, Southern Insect Management Research Unit, Stoneville, MS, USA \\ Email: *gino.medrano@usda.gov
}

How to cite this paper: Medrano, E.G., Glover, J.P., Bell, A.A. and Brewer, M.J. (2021) A Serratia marcesens Strains Involved in Cotton (Gossypium hirsutum) Boll Infection by a Prokaryote. Agricultural Sciences, 12, 1565-1578.

https://doi.org/10.4236/as.2021.1212100

Received: Novembwer 11, 2021

Accepted: December 28, 2021

Published: December 31, 2021

Copyright $\odot 2021$ by author(s) and Scientific Research Publishing Inc. This work is licensed under the Creative Commons Attribution International License (CC BY 4.0).

http://creativecommons.org/licenses/by/4.0/

\begin{abstract}
A boll infection caused by non-traditional cotton pathogens was first reported to occur in the southeastern U.S. Cotton Belt (year 2000) and has since spread to Texas causing significant yield losses. This study was aimed towards investigating the verde plant bug (Creontiades signatus) link between interior boll disease in Texas, USA. Using glasshouse grown bolls, bacteria recovered from locules with disease symptoms from field-grown cotton bolls caged with the piercing-sucking $C$. signatus were analyzed for the capacity to inflict the disease. For pathogenicity testing, spontaneously generated rifampicin resistant (Riff) variants were utilized to track the antibiotic resistant bacterium and deter growth of endophytic and contaminating bacteria. To simulate $C$. signatus feeding, a needle ( 31 gauge) was employed to inoculate bolls at 13 - 15 days after flower bloom. Bacterial suspensions ranged from $10^{1}-10^{6}$ colony forming units $/ \mathrm{ml}$. Field infection symptoms were duplicated after two weeks of bacterial exposure. Infectious strains were best categorized as Serratia marcescens based on traditional carbon utilization and enzyme production testing, and a $99 \%$ nucleotide sequence identity of $16 \mathrm{~S}$ ribosomal DNA. Putative $S$. marcescens representatives isolated from rotted bolls exposed to $C$. signatus were shown to reproduce field infection symptoms upon inoculation into greenhouse grown fruit. Serratia spp. can inflict disease in alfalfa, cucurbits, and sunflower. The presented data are the first to definitively show that a Serratia sp. has the capacity to infect cotton.
\end{abstract}

\section{Keywords}

Verde Plant Bug, Opportunistic Bacterial Infections, Antibiotic Selection 
Marker, Cotton Boll Disease, Piercing-Sucking Insects

\section{Introduction}

A recently reported boll disease in south Texas (USA) cotton (Gossypium hirsutum) is responsible for yield losses that can reach 15\% [1]. In the southeastern Cotton Belt, a similar malady is known [2] [3] [4]. In both situations, early detection is complicated since bolls of affected fields contain necrotic seed and lint yet, are absent of external infection symptoms [5] [6].

In south Texas, an emerging sucking pest called the verde plant bug (Creontiades signatus) has been associated with cotton yield losses [1]. The Gulf Coastal region of south Texas is where $C$. signatus naturally occurs. Native weedy plants that are reservoirs of $C$. signatus include London rocket, Sisymbrium irio L. (Brassicaceae), pigweed, Amaranthus spp. (Amaranthaceae), and nettleleaf goosefoot, Chenopodium murale L. (Chenopodiaceae) [7]. Creontiades signatus can propagate on cotton [8] [9]. Notably, C. signatus is of similar appearance and genetic makeup to $C$. dilues that is autochthonous to Australia and a major plant bug pest of cotton in that country [10] [11].

Here, we report the isolation and putative identification of opportunistic Serratia marcescens from immature, diseased cotton bolls from field plots in south TX that were previously exposed exclusively to $C$. signatus. Using glasshouse grown bolls, Koch's postulates were fulfilled demonstrating that $S$. marcescens strains have the capability to produce disease in cotton fruit analogous to those observed in the field.

Serratia marcescens was initially isolated from pond water and considered a non-pathogenic bacterial species that produces a reddish pigment on culture plates. Currently, Serratia strains are known to opportunistically infect both humans and certain plants. Specifically, plant pathogenic Serratia strains cause disease cucurbits, sunflower, and alfalfa [12]. Our findings are the first that concretely demonstrated a capacity of a Serratia species to infect cotton.

\section{Materials and Methods}

\subsection{Bacterial Isolation}

Cotton plants grown from Coker cultivar (cv.) seed in field plots at the Texas A\&M University-Extension Center-Corpus Christ (USA) were caged with and without field collected C. signatus bugs. In August (i.e., late in the regional growing season), unopened green bolls were collected, packaged with frozen gel packs, and transported overnight to the USDA-ARS Insect Control \& Cotton Disease Research Unit (ICCDRU) in College Station, Texas. Using 0.5\% sodium hypochlorite bolls, were sanitized for eight minutes $(1 \times)$ followed by sterile water rinses $(3 \times)$. Boll walls were dissected with a sterile surgical knife. Aprox- 
imately $1 \mathrm{~g}$ of diseased inner boll tissue with C. signatus bug feeding punctures was transported into a 1.1-ml microtube (SPEX SamplePrep; Metuchen, NJ) that contained $0.5 \mathrm{ml}$ of $\mathrm{PO}_{4}$ buffer $(0.1 \mathrm{~mol} / \mathrm{L}, \mathrm{pH} 7.1)$ and a stainless steel ball that was sterile (4-mm) in a $1.1 \mathrm{ml}$ tube (96 tubes/rack) for grinding (SPEX SamplePrep; Metuchen, NJ). Another ball was added and the tubes were sealed. The tissue was pulverized (5 min at 1500 strokes/min) with a $2000 \mathrm{Geno} / \mathrm{Grinder}$ (SPEX SamplePrep) and diluted with $0.5 \mathrm{ml}$ of $\mathrm{PO}_{4}$ buffer. The resulting homogenate was 10-fold dilution plated on Luria-Bertani agar (LBA; Difco Laboratories, Detroit, MI). Asymptomatic boll tissue was employed as controls and handled in the same manner as diseased tissue. All plates were incubated at $27^{\circ} \mathrm{C}$ until colonies were visible yet, not longer than two weeks. Remote colonies were dilution plated on LBA to ensure single cells. For long term storage, purified colonies suspended in LB (1\%) broth with diluted glycerol (40\%) were held at $-80^{\circ} \mathrm{C}$.

\subsection{Pathogenicity Tests}

Greenhouses were used to propagate cotton (cv. Coker) at the USDA-ARSICCDRU from seed for use in pathogenicity testing. The material used for planting was standard (dried peat moss, $12 \mathrm{~L}$, vermiculite, $12 \mathrm{~L}$; dolomitic lime, $300 \mathrm{ml}$; washed sand $18 \mathrm{~L}$; gypsum $1 \mathrm{~L}$; esmigran (Scotts-Sierra Horticultural Products Co., Marysvillee, $\mathrm{OH}$ ), $5 \mathrm{ml}$ ) and was added to $0.5 \mathrm{~kg}$ plastic pots. Reverse-osmosis water was used to saturate the containers. Aerated steam at $74^{\circ} \mathrm{C}$ for $16 \mathrm{~h}$ was used for pasteurization. Seeds were germinated a $48 \mathrm{~h}$ at $30^{\circ} \mathrm{C}$ in moist towels, and then implanted into the planting mixture. Thermostats settings were $30^{\circ} \mathrm{C}$ and $20^{\circ} \mathrm{C}$ for cooling and heating, respectively. A fertilizer (150 $\mathrm{mg}$ ) with chelated minor elements (Peter's Peat-Lite Special 15-16-17; Scotts-Sierra Horticultural Products Co., Marysvillee, $\mathrm{OH}$ ) was added weekly.

Bacteria recovered from individual diseased bolls with evidence of $C$. signatus bug feeding (i.e., punctures visible in the inner boll wall) were used in pathogenicity testing. Routine maintenance involved propagation on LBA plates at $27^{\circ} \mathrm{C}$ incubation. Remote colonies were utilized for all pathogenicity testing sterile Milli-Q (Millpore Sigma; Darmstadt, Germany) water was used to prepare bacterial suspensions from $18 \mathrm{~h}$ cultures grown on LBA and adjusted spectrophotometrically $\left(\mathrm{A}_{600}=1.0\right)$. Ultimate concentrations of $10^{1}, 10^{3}$, or $10^{6}$ colony forming units (CFU) of a bacterial inoculum were analyzed. As $C$. signatus feeds via a piercing mechanism a 31 gauge needle was used to breach the boll wall suture (c. $3-5 \mathrm{~mm}$ ) of bolls at $5-9$ or $13-15$ days post-anthesis (DPA). At 1 or 2 wks post-inoculation, bolls were longitudinally-sectioned along the suture and observed for presence/absence of disease symptoms with a set left to natural opening.

Spontaneously generated rifampicin resistant (Rif) mutants were generated by successively increased exposure of Rif sensitive remote colonies to the M9 minimal medium [13] amended with Rif reaching $200 \mu \mathrm{g} / \mathrm{ml}$. Antibiotic resis- 
tance to Rif was used for selection to distinguish between Rif ${ }^{\mathrm{r}}$ variants, and both endophytic and contaminating prokaryotes [14] [15]. Strains CC119R, CC113R and CC114R Rif ${ }^{\mathrm{r}}$ were derived from respective parental isolates that were recovered from separate diseased bolls and determined to be capable of producing infection symptoms in initial pathogenicity tests (Table 1). Antibiotic sensitive parental isolates were compared to the growth trajectory of the resistant variants as described before [16].

Infectivity of the Rif $^{\mathrm{r}}$ resistant mutants was compared to the respective parental strains that were sensitive to the antibiotic on green bolls (13 - 15 DPA). In triplicate, a single boll locule was inoculated for pathogenicity determination. Two independent studies were done. Using $18 \mathrm{~h}$ cultures, bacterial suspensions in sterile Milli-Q water were prepared and inoculated (method discussed above). Inoculations of $10 \mu \mathrm{l}$ of sterile water into locules were employed as negative controls. After two weeks, a visual analysis of infection was conducted. In addition, concentrations of bacteria were determined. Using a sodium hypochlorite solution $(0.5 \%)$, harvested bolls were washed independently for 10 minutes $(1 \times)$ and then rinsed for $8 \mathrm{~min}$ in sterile water $(3 \times)$. Boll walls were carved off using a sterile surgical knife. Locule tissue ( $c .1 \mathrm{~g}$ ) was placed in phosphate buffer and pulverized (discussed above). Following 10-fold serial dilution, samples were plated on nonselective media (LBA) and selective media (LBA amended added Rif at $200 \mu \mathrm{g} / \mathrm{ml}$ ). Following a $24 \mathrm{~h}$ incubation at $27^{\circ} \mathrm{C}$, colonies of bacterial from the seed and lint tissue were assessed (CFU/g locule tissue). A set of bolls were photographed at maturity (i.e., naturally expose the lint).

To measure the role of the mutant CC119 with Rif resistance (CC119R) on seed and lint infections, three concentrations were inoculated $\left(10^{1}, 10^{3}\right.$, or $10^{6}$

Table 1. Bacterial strains used in this study.

\begin{tabular}{clc}
\hline \multicolumn{1}{c}{ Strains } & \multicolumn{1}{c}{ Relevant characteristics } & Source \\
\hline Serratia marcscens & & American type culture collection \\
ATCC 13880 & Pond water, Type strain, Rifa sensitive & This study \\
CC119 & Diseased Coker cultivar boll from TX field plot, Rif sensitive & This study \\
CC113 & Diseased Coker cultivar boll from TX field plot, Rif sensitive & This study \\
CC114 & Diseased Coker cultivar boll from TX field plot, Rif sensitive & This study \\
CC119R & Derived from CC119; Rif resistant & This study \\
CC113R & Derived from CC113; Rif resistant & This study \\
CC114R & Derived from CC114; Rif resistant &
\end{tabular}

E. coli $\mathrm{K} 12$

ER2267

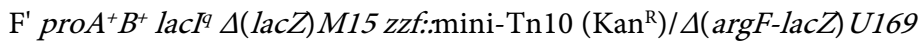
gIn V44 $\mathrm{e}^{-} 4^{-}\left(\mathrm{McrA}^{-}\right)$rfbD1? recA1 relA1? endA1 spoT1? thi-1 New England Biolabs, Inc. $\Delta($ mcrC-mrr) $114:: 1 S 10$

${ }^{\mathrm{a}}$ Rif $=$ Rifampicin; ${ }^{\mathrm{b}} \mathrm{TX}=$ Texas, USA. 
$\mathrm{CFU} / \mathrm{ml}$ ) into bolls at 13 - 15 after flower as using the methods discussed above. Antibiotic resistance was the basis for tracking of the mutant. CC119R cells heat-killed by exposure to $65^{\circ} \mathrm{C}$ for an hour were negative controls. Cell death of the samples were verified by plating on LBA.

A couple of independent tests were conducted to analyze disease expression. Including negative controls, both experiments consisted of triplicate inoculations of bacteria. After a two-week period, infection symptoms and/or nonsymptoms were determined by visual examination. Seed and lint tissue from inoculated locules (including both live and control samples) were analyzed for the presence of CC119R on non-selective (LBA) and (LBA with added antibiotic) media. The analysis involved the measurement of bacterial concentrations (CFU/g locule tissue) base plating 10-fold serial dilutions on both selective and nonselective media. Bolls inoculated with either CC11R or water (i.e., controls) were harvested after a two-week period and assessed for disease. As above, bacterial concentrations from both seed and lint tissue were based on plating all samples on non-selective media following serial dilutions (10-fold).

\subsection{Pathogen Characterization Based on Phenotype}

Representative bacteria (CC119, CC113, and CC114) recovered from separate diseased field bolls with similar symptoms and colony types, and a demonstrated capacity to produce disease in greenhouse grown bolls with comparable symptoms to the original field-grown bolls were further characterized as described before [16] [17]. In brevity, testing consisted of Gram staining, growth in anaerobic conditions, production of oxidase and catalase along with characteristic color of a colony on LBA. The control used in all testing was the Serratia marcscens type strain (ATCC 13880). Those isolates generally identified as Enterobacteriaceae were subsequently putatively categorized to species. For expanded phenotypic characterization, Analytical Profile Index test strips (API 20E; bioMerieux, Inc., Durham, NC) were used following the manufacturer's protocol along with incorporating the $S$. marcescens type strain.

\subsection{Categorization Based on 16 S Ribosomal DNA Sequence}

A Polymerase Chain Reaction (PCR) primer set designed previously [16] to generate a $16 \mathrm{~S}$ ribosomal product was utilized. The predicted $1.4 \mathrm{~K}$ base pair fragment based on $E$. coli positioning was ligated into the XbaI-NotI sites of the pDrive cloning vector (New England Biolabs Inc., Beverly, MA) then transformed into E. coli ER2267 (Table 1) by the $\mathrm{CaCl}_{2}$ method [13]. Sequencing was performed at the Institute of Developmental and Molecular Biology, Gene Technologies Laboratory at Texas A\&M University on a contract basis. Derived 16S rDNA gene sequence data from both strands were edited and assembled using Sequencher 4.8, and then compared to sequences in the GenBank database using the BLAST program available at the National Center for Biotechnology Information (http://www.ncbi.nlm.nih.gov/BLAST/). A Qiagen kit (Valencia, 
CA) was used for all PCR experiments with an amplification protocol that consisted of an initial denaturation step at $96^{\circ} \mathrm{C}$ for $5 \mathrm{~min}$ followed by 30 cycles of denaturation at $95^{\circ} \mathrm{C}$ for $1 \mathrm{~min}$, annealing at $55^{\circ} \mathrm{C}$ for $1 \mathrm{~min}$ and extension at $72^{\circ} \mathrm{C}$ for 1 min with a final extension at $72^{\circ} \mathrm{C}$ for 5 min using a PTC-200 DNA Engine Cycler (MJ Research Inc., Waltham, MA).

The generated 16S rDNA sequence from isolate CC119 was compared with the type strains of several $\alpha$ subclass of the Proteobacteria species including Serratia marcescens ATCC 13880 (AB681729.1). The phylogenetic analysis was performed using MEGAX [18] Juke-Cantor calculated distances, and a tree was constructed using the Unweighted Pair Group Method Average (UPGMA). The tree was assembled to scale, with branch lengths (above the branches) in the same units as those of the evolutionary distances used to infer the phylogenetic tree. Bootstrapping was conducted for 1000 replicates with confidence levels greater $50 \%$ indicated at the tree internodes.

\section{Results}

\subsection{Bacterial Isolation}

The bolls feed upon by the insects resulted in disease whereas, infection symptoms were not apparent in bolls from plants not exposed to insects. Bacteria were isolated from 10 -fold serial dilution plating of pulverized homogenate from discolored seed and lint. Colony morphology of a majority of the bacteria isolated from diseased seed and lint tissue was mucoid with smooth, entire margins, an umbonate elevation, and a reddish pigmentation on LBA. Preliminary identification of isolated and suspected pathogens indicated that they were best classified as Serratia species. Yeasts were not detected from any of the rotted bolls in the pilot field study. Bacteria were not detected in the asymptomatic tissue samples.

\subsection{Pathogenicity Tests}

Three isolates designated CC119R, CC113R, and CC114R were used in all tests to measure the optimal inoculation method. Disease symptom development at one week post-inoculation occurred in tissue surrounding the injection (c. 3 $\mathrm{mm}$ ) with spotty yellowish pink discoloration of the seed coat. In contrast, seed and lint necrosis was visible throughout the inoculated locule two, three and four weeks post-inoculation. Each of the three representative isolates tested by wound inoculation consistently resulted in disease and locule rot.

The antibiotic resistance marker was employed to fulfill Koch's postulates and measure bacterial densities in inoculated fruit. The spontaneously derived Rif resistant mutants for the isolates (CC119R, CC113R, and CC114R) were determined to be capable of causing seed and boll rot. Rifampicin resistance for CC119R, CC113R, and CC114R was stable for the two week testing period. Based on dilution plating and colony counts on LBA, growth patterns between 
the Rif resistant mutants and their respective parental strains (CC119, CC113, and CC114) were essentially equal.

Simulated $C$. signatus feeding was utilized to compare the infection potential of the Rif $^{\mathrm{r}}$ and respective Rif sensitive parental strains. An amendment to the technique consisted of injecting bacteria with a syringe and 31 gauge needle at a final concentration of $10^{3} \mathrm{CFU} / \mathrm{ml}$. Bacteria were not recovered from asymptomatic control locules (Figure 1) that were injected with sterile water and plated on either selective or non-selective media two weeks post-inoculation. Following the two-week incubation period, locules inoculated with parental strains were consistently diseased with bacterial concentrations of $10^{8} \mathrm{CFU} / \mathrm{g}$ tissue on LBA, whereas no bacteria were detected on parallel Rif amended LBA plates. Disease symptoms and bacterial populations $\left(10^{8} \mathrm{CFU} / \mathrm{g}\right)$ in locules inoculated with the Rif mutants were comparable to those of parental strains. Notably, the Rif mutants were detected at equivalent levels on LBA with or without Rif. Locules from bolls that were injected with sterile water two weeks post-anthesis, and then grown to maturity had scar tissue just about the site of the initial inoculation (Figure 1(C)). Matured open bolls with locules that were inoculated with either the Rif ${ }^{\mathrm{f}}$ mutants or the parental types developed necrosis of the entire locule.

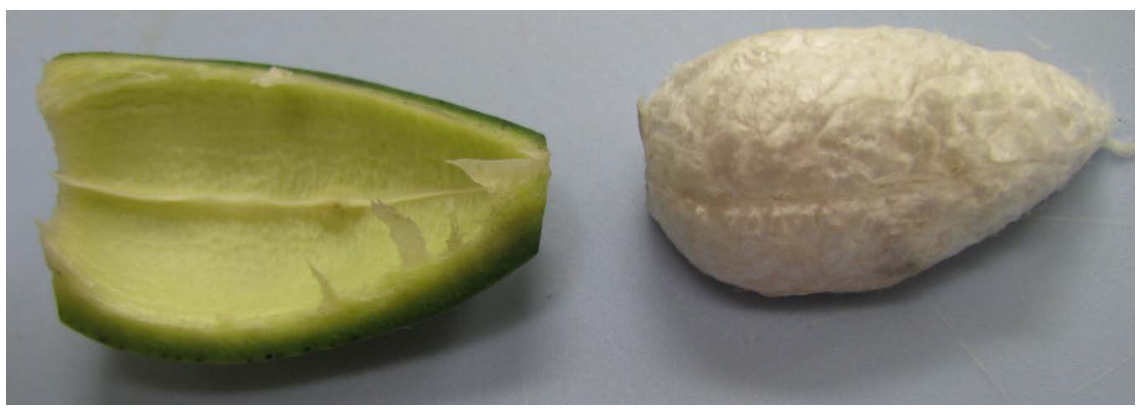

(A)

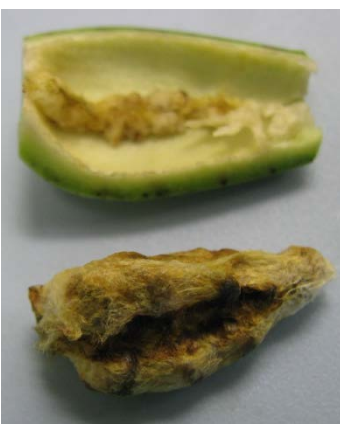

(B)

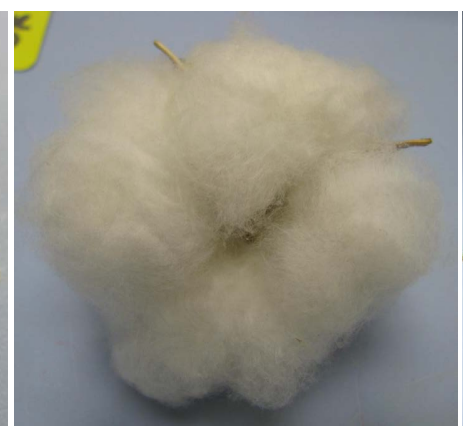

(C)

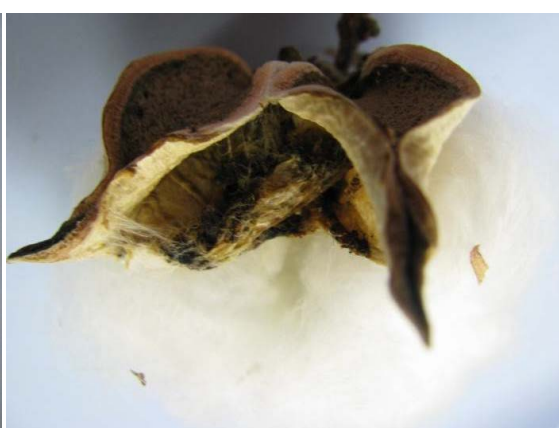

(D)

Figure 1. Differences between control and diseased greenhouse grown fruit with a locule inoculated two weeks post-anthesis using a 31 gauge needle. (A) A locule injected with $10 \mu$ of sterile water showing no apparent infection symptoms two weeks post-inoculation. (B) A locule injected with strain CC119R showing disease symptoms two weeks post-inoculation. (C) An open boll showing a locule injected with $10 \mu \mathrm{l}$ of sterile water two weeks post-anthesis with a minimal scar tissue from the initial puncture wound. (D) An open boll showing a locule injected with strain CC119R two weeks post-anthesis showing a matted, deteriorated boll. 
Seed from diseased locules were sectioned and contained shriveled and brown embryos. Irrespective of use of parental strains or the Rif resistant mutants, disease occurred only in locules that were injected with bacteria.

The disease produced by either the parental or Rif ${ }^{\mathrm{r}}$ variants resulted in similar infection symptoms. Thus, the Rif resistant mutant CC119R was exclusively used at a range of concentrations to examine potential effects of inoculum on disease symptom expression and bacterial populations (Table 2). As in field samples, none of the inoculated concentrations used produced exterior boll rot symptoms. Injections of CC119R at either $10^{3}$ or $10^{6} \mathrm{CFU} / \mathrm{ml}$ resulted in locule symptoms analogous to field infected boll samples with bacterial concentrations detected at $10^{8} \mathrm{CFU} / \mathrm{g}$ two weeks following the inoculations (Table 2). Disease symptoms were contained to the inoculated locule two weeks after injecting bolls with $10^{8} \mathrm{CFU} / \mathrm{ml}$ of the mutant. The locule tissue was completely withered, and bacterial concentrations reached $10^{9} \mathrm{CFU} / g$ of diseased tissue. In contrast, locules injected with either heat-killed cells or sterile water appeared healthy (Table 2). Growth was not detected from cell suspensions of either $10^{1}, 10^{3}$, or $10^{6} \mathrm{CFU} / \mathrm{ml}$ on LBA following inoculation of heat-killed cells.

Table 2. Detection of strain CC119R from locule tissue of inoculated greenhouse grown cotton fruit.

\begin{tabular}{lccc}
\hline $\begin{array}{l}\text { Inoculation } \\
\left(\mathrm{CFU} \mathrm{ml} l^{-1}\right)\end{array}$ & Boll appearance $^{\mathrm{a}}$ & $\begin{array}{c}\text { Bacteria recovered }^{\mathrm{b}} \\
\text { Bacteria recovered }^{\mathrm{b}}\end{array}$ \\
\hline
\end{tabular}

\section{CC119R}

\begin{tabular}{|c|c|c|c|}
\hline $10^{6}$ & $\begin{array}{c}\text { No exterior symptoms; entire } \\
\text { locule infected and rotted }\end{array}$ & $1 \times 10^{10} \mathrm{CFU} / \mathrm{g}$ & $1 \times 10^{10} \mathrm{CFU} / \mathrm{g}$ \\
\hline $10^{3}$ & $\begin{array}{c}\text { No exterior symptoms; entire } \\
\text { locule infected and rotted }\end{array}$ & $5 \times 10^{8} \mathrm{CFU} / \mathrm{g}$ & $5 \times 10^{8} \mathrm{CFU} / \mathrm{g}$ \\
\hline $10^{1}$ & $\begin{array}{c}\text { No exterior symptoms; entire } \\
\text { locule infected and rotted }\end{array}$ & $5 \times 10^{8} \mathrm{CFU} / \mathrm{g}$ & $5 \times 10^{8} \mathrm{CFU} / \mathrm{g}$ \\
\hline \multicolumn{4}{|c|}{ CC119R ${ }^{\mathrm{d}}$ (heat-killed) } \\
\hline $10^{6}$ & $\begin{array}{l}\text { Puncture mark visible; no } \\
\text { discoloration of locule }\end{array}$ & $<10^{1} \mathrm{CFU} / \mathrm{g}$ & $<10^{1} \mathrm{CFU} / \mathrm{g}$ \\
\hline $10^{3}$ & $\begin{array}{l}\text { Puncture mark visible; no } \\
\text { discoloration of locule }\end{array}$ & $<10^{1} \mathrm{CFU} / \mathrm{g}$ & $<10^{1} \mathrm{CFU} / \mathrm{g}$ \\
\hline $10^{1}$ & $\begin{array}{l}\text { Puncture mark visible; no } \\
\text { discoloration of locule }\end{array}$ & $<10^{1} \mathrm{CFU} / \mathrm{g}$ & $<10^{1} \mathrm{CFU} / \mathrm{g}$ \\
\hline $\mathrm{H}_{2} \mathrm{O}$ & $\begin{array}{l}\text { Puncture mark visible; no } \\
\text { discoloration of locule }\end{array}$ & $<10^{1} \mathrm{CFU} / \mathrm{g}$ & $<10^{1} \mathrm{CFU} / \mathrm{g}$ \\
\hline
\end{tabular}

a Suspensions of bacteria in sterile water were injected using a 31-gauge needle into a sin-

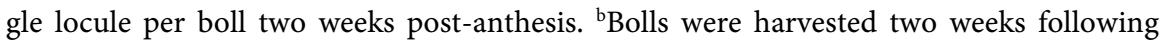
inoculations and dilution plated on both Luria-Bertani agar (LBA) medium and LBA amended with rifampicin $(200 \mu \mathrm{g} / \mathrm{ml})$ reported in colony forming units $(\mathrm{CFU}) .{ }^{\mathrm{c}} \mathrm{Rif}=\mathrm{Ri}$ fampicin. ${ }^{\mathrm{d} C e l l s}$ were exposed to $65^{\circ} \mathrm{C}$ for $1 \mathrm{~h}$. 
Strain CC119R was further employed to examine effects of boll age at inoculation on both the severity of rot symptoms and bacterial densities (Table 3). Bolls injected less than six DPA were aborted, cavitated, or had split prematurely. Bolls inoculated with CC119R at 6 - 8 DPA had extensive disintegration of the locules leaving only a small mummified, sooty black residue. Thus, bacterial densities were not determined (Table 3). Control bolls 6 - 8 DPA were prone to fungal contamination. Locules from bolls inoculated 13 - 15 DPA with CC119R exhibited symptoms that resembled the infected field cotton bolls (Figure 2) from which the CC119R parental strain was isolated. Disease symptoms from the inoculated locule such as dark spots or stripes that developed immediately and contiguously under the suture were apparent throughout the tissue. The lint was stained brown, decomposed, and not viscous. The non-inoculated locules from the same bolls did not show disease symptoms. Levels of CC119R in infected locules were consistent with densities determined from studies that compared the Rif mutants and the parental strains $\left(10^{8} \mathrm{CFU} / \mathrm{g}\right)$. Bolls inoculated at 20 - 28 DPA with derivative CC119R expressed symptoms that extended only to the area immediately surrounding the injection point. Bacterial densities from locules inoculated 20 - 28 DPA were detected at 10-fold lower levels than populations from bolls inoculated 13-15 DPA.

\subsection{Phenotypic Characterization and 16S Ribosomal DNA Sequencing of the Pathogens}

Isolates CC119, CC113, and CC114 were Gram negative, rod-shaped, facultative anaerobes, and catalase positive. With the exception of the gelatinase test, the API 20E results for the three unknown isolates were identical to the reactions of the $S$. marcescens type strain (Table 4). Isolate CC113 and $S$. marcescens ATCC 13880 did not liquefy the charcoal gelatin, whereas isolates CC1119 and CC114 diffused the substrate after $24 \mathrm{~h}$. A $1.4 \mathrm{~kb}$ portion of the $16 \mathrm{~S}$ rDNA gene for isolate CC119 was cloned and sequenced. The percentage of identities between sequence from the tested isolates was $99 \%$ when compared to the $16 \mathrm{~S}$ rDNA of $S$. marcescens strain SM2617 and SM2618 (Figure 3).

Table 3. Disease symptoms resulting from wound inoculation of cotton cv. Coker at different boll ages with strain CC119R.

\begin{tabular}{|c|c|c|c|c|}
\hline \multirow[b]{2}{*}{ Boll age at inoculation } & \multicolumn{2}{|l|}{$\mathrm{CC} 119 \mathrm{R}^{\mathrm{a}}$} & \multicolumn{2}{|l|}{ Control $^{\mathrm{b}}$} \\
\hline & Boll appearance ${ }^{c}$ & $\begin{array}{l}\text { Bacteria }^{\mathrm{d}} \\
\text { recovered }\end{array}$ & Boll appearance & $\begin{array}{l}\text { Bacteria } \\
\text { recovered }\end{array}$ \\
\hline 6 - 8 days post-anthesis & rot of all locules; boll abscission & not done & mark at inoculation point $(c .1 \mathrm{~mm})$ & not done \\
\hline 13 - 15 days post-anthesis & entire locule infected and rotted & $5 \times 10^{8} \mathrm{CFU} /$ & g mark at inoculation point $(c .1 \mathrm{~mm})$ & $<10^{1} \mathrm{CFU} / \mathrm{g}$ \\
\hline
\end{tabular}

${ }^{a} \mathrm{~A}$ bacterial suspension in sterile water was inoculated through the capsule of a single locule at a final concentration of $10^{3} \mathrm{CFU} / \mathrm{ml}$ using a 31-gauge needle. ${ }^{b}$ Mock inoculations of bolls involved injecting sterile water $(20 \mu \mathrm{l})$ into the capsule of a single locule using

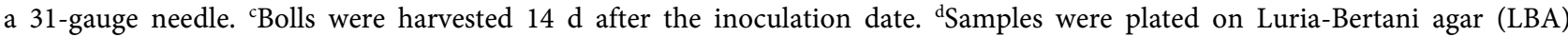
amended with rifampicin $(200 \mu \mathrm{g} / \mathrm{ml})$ reported in colony forming units (CFU). 


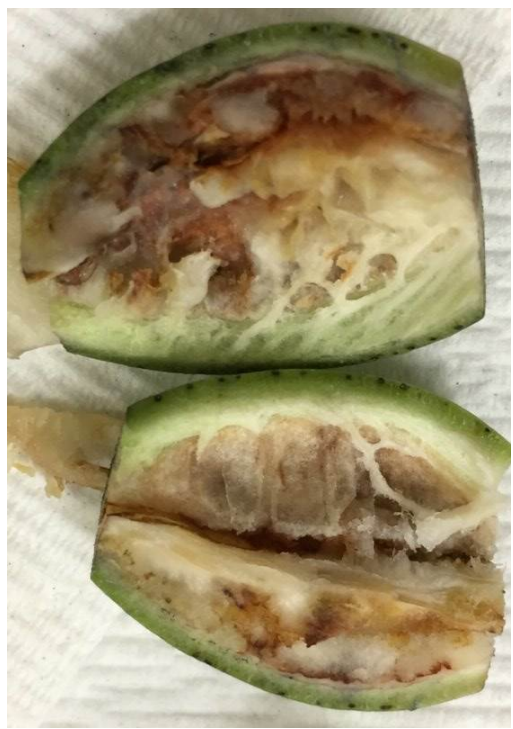

(A)

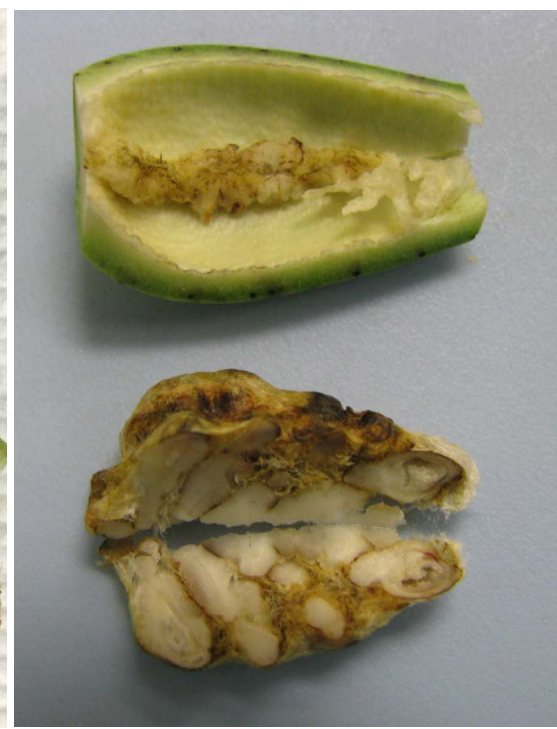

(B)

Figure 2. Symptom expression of diseased cotton fruit. (A) Field infected cotton boll samples exposed to $C$. signatus. (B) Greenhouse grown fruit injected two weeks post-anthesis with strain CC119R using a 31 gauge needle, and then harvested two weeks post-inoculation.

Table 4. Phenotypic and biochemical characteristics of isolates CC119, CC113, and CC114 that included the Serratia marcescens type strain ATCC 13880.

\begin{tabular}{|c|c|c|c|c|}
\hline Test & CC119 & $\mathrm{CC} 113$ & $\mathrm{CC} 114$ & S. marcescens \\
\hline Reddish pigment on LBA & + & + & + & + \\
\hline Growth at $37^{\circ} \mathrm{C}$ & + & + & + & + \\
\hline Motility & + & + & + & + \\
\hline \multicolumn{5}{|l|}{ Production of ${ }^{\mathrm{a}}$ : } \\
\hline Beta-galactosidase & + & + & + & + \\
\hline Arginine dihydrolase & - & - & - & - \\
\hline Lysine decarboxylase & - & - & - & - \\
\hline Ornithine decarboxylase & - & - & - & - \\
\hline $\mathrm{H}_{2} \mathrm{~S}$ & - & - & - & - \\
\hline Deaminase & - & - & - & - \\
\hline Indole & - & - & - & - \\
\hline Acetoin (Voges-Proskauer reaction) & + & + & + & + \\
\hline Gelatinase & + & - & + & - \\
\hline Citrate utilization $^{\mathrm{a}}$ & - & - & - & - \\
\hline Urea hydrolysis $^{\mathrm{a}}$ & - & - & - & - \\
\hline \multicolumn{5}{|l|}{ Acid production from ${ }^{\mathrm{a}}$ : } \\
\hline Glucose & + & + & + & + \\
\hline Mannitol & + & + & + & + \\
\hline Inositol & - & - & - & - \\
\hline
\end{tabular}




\section{Continued}

\begin{tabular}{lllll}
\hline Sorbitol & - & - & - & - \\
Rhamnose & + & + & + & + \\
Sucrose & + & + & + & + \\
Melibiose & - & - & - & - \\
Amygdalin & + & + & + & + \\
Arabinose & + & + & + & + \\
Oxidase & - & - & - & -
\end{tabular}

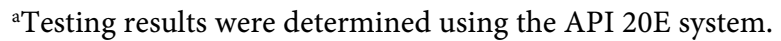

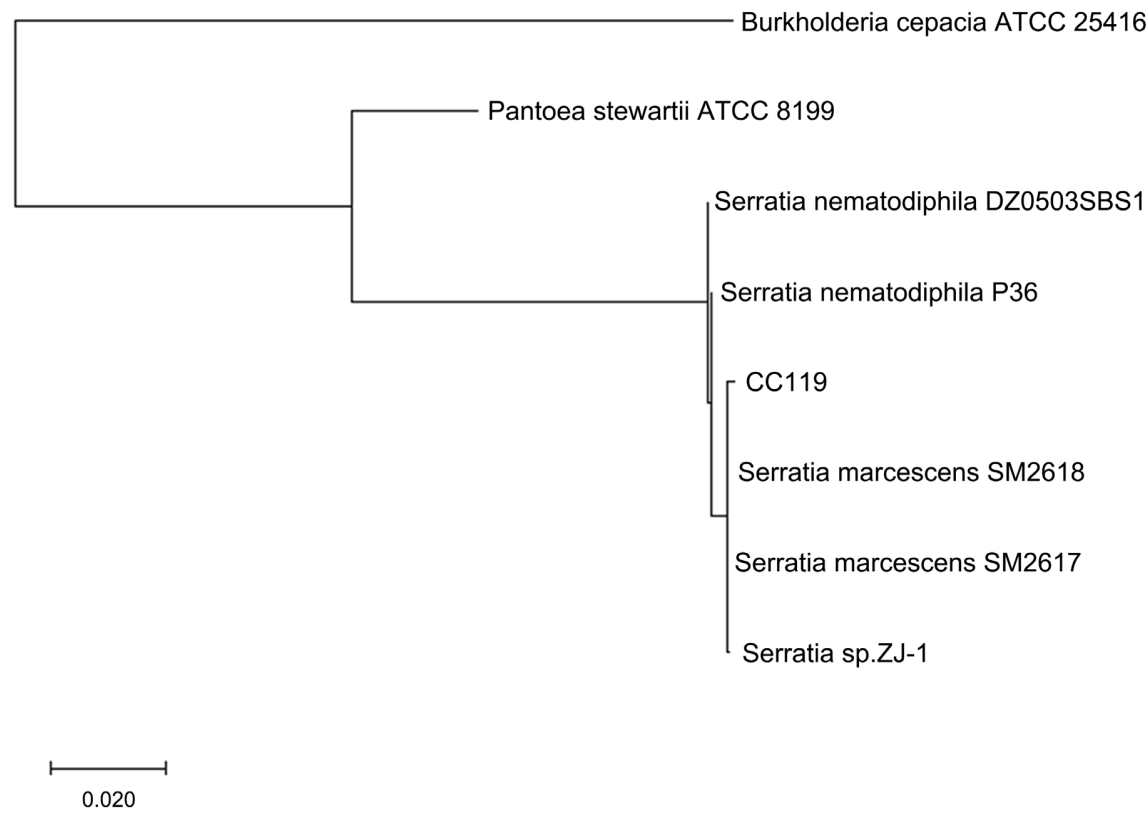

Figure 3. Phylogenetic tree of $16 \mathrm{~S}$ rDNA showing the relationships among the boll infected isolates, and type strains for several $\alpha$ subclass of the Proteobacteria species. The sequences were aligned in Clustal W. Juke-Cantor distances were calculated and the tree was constructed in molecular evolutionary genetics analysis (MEGAX) using the Unweighted Pair Group Method Average (UPGMA) [18]. Bootstrapping was done for 1000 replicates and confidence levels greater than $50 \%$ are indicated at the internodes.

\section{Discussion}

Diseased fruit resulted from caging of field green bolls with field collected $C$. signatus bugs that feed using a sucking method. Conversely, disease was not detected in insect-free bolls suggesting association between $C$. signatus bug feeding and pathogen transmission. Other boll pests that feed via a piercing-sucking mechanism and are responsible for vector-borne infections include both the brown and southern green stink bugs [19] [20] [21].

The predominant bacterial colony morphology type consisted of a reddish hue. Representatives were shown to be capable of inflicting disease in greenhouse grown bolls with symptoms that resembled infected field boll samples 
(Figure 2). Infection spread throughout the inoculated locule by two weeks post-inoculation (Figure 1). Consistent with cracked diseased field fruit pathogen inoculated greenhouse grown bolls were matted at maturity with lint and seed stained brown (Figure 1).

Resistance to Rif was introduced into isolates determined to cause boll disease for use as a selection marker to differentiate between Rif sensitive contaminants and the inoculated Rif ${ }^{\mathrm{r}}$ mutants. The rifampicin mode of action consists of a broad bacterial host range with irreversible binding to the $B$-subunit of RNA polymerase; therefore, blocking bacterial transcription [22]. The stability of Rif ${ }^{\mathrm{r}}$ in generated variants was used to study root colonization in field work [23]. Here, Rif ${ }^{\mathrm{r}}$ was determined to holdfast in resistant derivatives propagated under non-selective conditions and thus, used to fulfill Koch's postulates.

\section{Conclusions}

In the current report, we showed that infection of immature bolls of greenhouse grown cotton produced symptoms similar to those observed in field grown bolls exposed to $C$. signatus. Bolls infested by the southern green stink bug (Nezara viridula L.) have reportedly caused an increase in the incidence of "hard-locks." Injury due to insect feeding was not consistently detected. Further, reductions in disease incidence result from the application of insecticides to cotton fields with a history of inner boll rot. Hence, bacterial recovery from diseased field grown boll continues in efforts to study a possible spectrum of opportunistic species and prospective seasonal variations.

The whole genome of Serratia strain CC119 was recently sequenced for the purpose of identifying gene products potentially involved in boll infection. Several potential pathogenicity and virulence genes were revealed including porins and invasins. Disease determinants shall be used to develop a PCR-based system to directly detect the pathogen from field samples. The molecular technique will simplify the costly and laborious process that now encompasses traditional culture and classification procedures that involve isolating and identifying bacteria followed by disease testing to distinguish between saprophytic and pathogenic strains.

\section{Acknowledgements}

Thanks are due to Richard M. Hernandez for technical and editorial support.

\section{Funding}

This work was partially funded by a Cotton Incorporated Grant (Project \#17-535TX) to EGM.

\section{Author Contributions}

EGM conceived the study and conducted the bacteriology work. JPG and MJB 
conducted field work in Corpus Christi, TX. AAB conducted glasshouse work in College Station, TX.

\section{Conflicts of Interest}

The authors declare no conflicts of interest regarding the publication of this paper.

\section{References}

[1] Brewer, M.J., Armstrong, J.S., Medrano, E.G. and Esquivel, J.F. (2012) Verde Plant, Creontiades signatus (Hemiptera: Miridae), Is Associated with Cotton Boll Rot. Journal of Cotton Science, 16, 144-151.

[2] Greene, J.K., Turnipseed, S.G., Sullivan, M.J. and May, O.L. (2001) Treatment Thresholds for Stink Bugs (Hemiptera: Pentatomidae) in Cotton. Journal of Economic Entomology, 94, 403-409. https://doi.org/10.1603/0022-0493-94.2.403

[3] Medrano, E.G., Esquivel, J.F., Nichols, R.L. and Bell, A.A. (2009) Temporal Analysis of Cotton Boll Symptoms Resulting from Southern Green Plant Bug (Nezara viridula L.) Feeding and Transmission of a Bacterial Pathogen. Journal of Economic Entomology, 102, 36-42. https://doi.org/10.1603/029.102.0106

[4] Willrich, M.M., Leonard, B.R. and Padgett, G.B. (2004) Influence of Southern Green Stink Bug, Nezara viridula L., on Late-Season Yield Losses in Cotton, Gossypium hirsutum L. Environmental Entomology, 33, 1095-1101. https://doi.org/10.1603/0046-225X-33.4.1095

[5] Mauney, J.R. and Stewart, J. (2003) Embryo Development in Bolls Exhibiting the "Hollow Seed" Syndrome in South Carolina. 2002-2004 CD-ROM Version of Proceedings of the Beltwide Cotton Conferences.

[6] Mauney, J.R., Stewart, J. and Jones, M.A. (2004) Onset and Progression of the "Hollow Seed" (Seed Rot) Maladay of South Carolina. 2002-2004 CD-ROM Version of Proceedings of the Beltwide Cotton Conferences.

[7] Coleman, R.J. (2007) Creontiades signatus. A Plant Bug Pest of Cotton in South Texas. Proceedings of Beltwide Cotton Conference, New Orleans, 8-11 January 2007, 38-41.

[8] Armstrong, J.S., Coleman, R.J. and Setamou, M. (2009) Oviposition Patterns of Creontiades signatus (Heteroptera: Miridae) on Okra-Leaf and Normal-Leaf Cotton. Annals of the Entomological Society of America, 102, 196-200. https://doi.org/10.1603/008.102.0202

[9] Armstrong, J.S., Coleman, R.J. and Duggan, B.L. (2010) Actual and Simulated Injury of Creontiades signatus Distant (Heteroptera: Miridae) Feeding of Cotton Bolls. Journal of Entomological Science, 45, 170-177. https://doi.org/10.18474/0749-8004-45.2.170

[10] Coleman, R.J, Hereward, J.P., De Barro, P.J., Frohlich, D.R., Adamczyk Jr., J.J. and Goolsby, J.A. (2008) Molecular Comparison of Creontiades Plant Bugs from South Texas and Australia. Southwestern Entomologist, 33, 111-117. https://doi.org/10.3958/0147-1724-33.2.111

[11] McColl, S.A., Khan, M. and Umina, P.A. (2011) Review of the Biology and Control of Creontiades dilutus (Stal) (Hemiptera: Miridae). Australian Journal of Entomology, 50, 107-117. https://doi.org/10.1111/j.1440-6055.2010.00800.x

[12] Petersen, L.M. and Tisa, L.S. (2013) Friend or Foe? A Review of the Mechanisms 
That Drive Serratia towards Diverse Lifestyles. Canadian Journal of Microbiology, 59, 627-640. https://doi.org/10.1139/cjm-2013-0343

[13] Sambrook, J., Fritsch, E.F. and Maniatis, T. (1989) Molecular Cloning. A Laboratory Manual. Cold Spring Harbor Laboratory Press, Cold Spring Harbor.

[14] Adams, P.D. and Kloepper, J.W. (2002) Effect of Host Genotype on Indigenous Bacterial Endophytes of Cotton (Gossypium hirsutum L.). Plant and Soil, 240, 181-189. https://doi.org/10.1023/A:1015840224564

[15] Misaghi, I. and Donndelinger, C.R. (1990) Endophytic Bacteria in Symptom-Free Cotton Plants. Phytopathology, 80, 808-811. https://doi.org/10.1094/Phyto-80-808

[16] Medrano, E.G., Esquivel, J.F. and Bell, A.A. (2007) Transmission of Cotton (Gossypium hirsutum) Seed and Boll Rotting Bacteria by Southern Green Stink Bugs ( $\mathrm{Ne}$ zara viridula). Journal of Applied Microbiology, 103, 436-444. https://doi.org/10.1111/j.1365-2672.2006.03262.x

[17] Schaad, N.W., Jones, J.B. and Chun, W. (2001) Laboratory Guide for Identification of Plant Pathogenic Bacteria. 3rd Edition, APS Press, St. Paul.

[18] Kumar, S.K., Stecher, G., Kryaz, C. and Tamura, K. (2018) MEGAX: Molecular Evolutionary Genetics Analysis across Computing Platforms. Molecular Biology and Evolution, 36, 1547-1549. https://doi.org/10.1093/molbev/msy096

[19] Medrano, E.G., Bell, A.A. and Duke, S.E. (2016) Cotton (Gossypium hirsutum L.) Boll Rotting Bacteria Vectored by the Brown Stink Bug, Euschistus servus (Say) (Hemiptera: Pentatomidea). Journal of Applied Microbiology, 121, 757-766. https://doi.org/10.1111/jam.13197

[20] Medrano, E.G., Bell, A.A. and Duke, S.E. (2016) Cotton (Gossypium hirsutum L.) Boll Rotting Bacteria Vectored by the Brown Stink Bug, Euschistus servus (Say) (Hemiptera: Pentatomidea). Journal of Applied Microbiology, 121, 757-766. https://doi.org/10.1111/jam.13197

[21] Muhammad, E., Muhammad, A.K., Muhammad, T.J., Muhammad, A. and Abdul, R. (2014) Pathogenic Aspects of Pantoea agglomerans in Relation to Cotton Boll Age and Dysdercus cingulatus (Fabricius) Transmitting Seed and Boll Rot in Cotton Germplasm. Archives of Phytopathology and Plant Protection, 47, 1815-1826. https://doi.org/10.1080/03235408.2013.858878

[22] Campbell, E.A., Korzheva, N., Mustaev, A., Murakami, K., Nair, S., et al. (2001) Structural Mechanism for Rifampicin Inhibition of Bacterial RNA Polymerase. Cell, 104, 901-912. https://doi.org/10.1016/S0092-8674(01)00286-0

[23] Glandorf, D.C.M., Brand, I., Bakker, P.A.H.M. and Schippers, B. (1992) Stability of Rifampicin as a Marker for Root Colonization Studies of Pseudomonas putida in the Field. Plant and Soil, 147, 135-142. https://doi.org/10.1007/BF00009379 